\title{
SEBUAH STUDI NIAT BELI SKINCARE: PENGARUH SOCIAL MEDIA MARKETING, E-WOM, DAN IN-STORE DISPLAY
}

\author{
Heristya Putri \\ Universitas Negeri Surabaya \\ heristya.17080574098@mhs.unesa.ac.id
}

\begin{abstract}
Several factors can be used to determine the success of consumer purchase intentions. In this study, the factors that can influence purchase intention are formed from social media marketing, e-commerce, and in-store displays. The purpose of this study was to determine the effect of social media marketing, e-WOM, and in-store displays on purchase intention of skincare products (study on consumers of Rena beauty store-Tuban). This research is quantitative. The sampling technique used was non-probability sampling with judgmental methods. The sample used was 100 people. The respondent in this study has seen the contents of Tiktok owned by Rena beauty store and has never purchased skincare products at Rena beauty store, with an age range of 17-35 years. The measurement scale uses the Likert scale. The measurement method used is a questionnaire, data analysis using multiple linear regression equation models. The data is processed using SPSS version 26. The results of this study indicate that social media marketing has a significant effect on the intention to buy skincare products for consumers in Rena beauty store-Tuban; meanwhile, e-WOM has no significant effect on the intention to buy skincare products for consumers because beauty store-Tuban, the in-store display also does not affect. Significantly on the intention to buy skincare products to consumers of Rena beauty store-Tuban.
\end{abstract}

Keywords: electronic word of mouth, in-store display; purchase intention; social media marketing.

\section{PENDAHULUAN}

Masyarakat begitu dimudahkan dengan teknologi dan berbagai macam aktivitas online di era modern seperti sekarang. Aktivitas tersebut diantaranya bekerja, sekolah, mencari informasi, hingga kemudahan berbelanja secara online. Beberapa lapisan masyarakat menggunakan social media untuk memasarkan sebuah produk secara online. Social media memiliki dampak yang baik dan dampak yang buruk, untuk itu penggunaan social media harus dilakukan dengan bijak (Ramadhani, 2020). Social media seperti Instagram, Facebook, Whatsapp, Tiktok, dan aplikasi lainnya pada awalnya hanya berfungsi sebagai hiburan semata, namun saat ini beberapa social media beralih fungsi menjadi platform yang bisa kita gunakan untuk memasarkan produk yang akan kita jual. Pengguna social media yang terus bertambah, maka akan sangat menguntungkan bagi para penjual yang mengenalkan produknya melalui social media (Cakra, 2020).

Social media marketing mempunyai pengaruh signifikan pada niat beli konsumen (Balakrishnan, Dahnil, \& Yi, 2014). Social media yang diambil dalam penelitian ini adalah Tiktok, di mana aplikasi Tiktok merupakan aplikasi non game yang sangat digemari di masa sekarang (Sari, 2020). Pengguna aktif Tiktok sampai dengan bulan Juli 2020 mencapai 689,17 juta pengguna, dan ini masih dapat terus bertambah karena semakin tertariknya para pengguna social media terhadap Tiktok (Franedya, 2020). Hal ini dapat dikatakan sebagai prestasi yang menakjubkan yang telah dicapai oleh Tiktok, mengingat Tiktok merupakan sebuah aplikasi yang masih berusia sangat muda yaitu 4 tahun. Indonesia sendiri menyumbang $11 \%$ keseluruhan total unduhan Tiktok. Total unduhan Tiktok di seluruh dunia telah mencapai jumlah lebih dari 63,3 juta pengunduhan, hal ini mengalami peningkatan sebesar terjadi 1,6\% sejak Agustus 2019 (Franedya, 2020). Pengguna aktif Tiktok yang cukup banyak memengaruhi proses pemasaran bagi para penjual online di Indonesia, misalnya dengan cara membuat content yang berisi tentang informasi produk (manfaat dan komposisi) yang mereka jual, dibantu dengan tulisan atau caption dan hashtag, dengan begitu calon konsumen akan lebih mudah mendapatkan informasi yang mereka inginkan (Dewi, 2020).

E-WOM merupakan pemasaran menggunakan internet untuk menciptakan efek berita dari mulut ke mulut untuk mendukung usaha dan tujuan pemasaran (Kotler \& Keller, 2016). E-WOM adalah sebuah 
Heristya Putri. Sebuah Studi Niat Beli Skincare: Pengaruh Social media Marketing, E-WOM, dan Instore Display

pernyataan yang baik atau buruk dari calon pembeli atau pembeli lama terhadap suatu barang atau perusahaan yang disediakan untuk masyarakat atau instansi dengan bantuan internet (Hennig-Thurau, Gwinner, Walsh, \& Gremler, 2004).

In-store display dapat digambarkan sebagai tampilan dalam toko yang dirancang semenarik mungkin dengan tujuan mencuri perhatian dari seseorang yang datang dalam toko tersebut (Jaya \& Suparna, 2018). In-store display yang menarik bisa menambah pembelian yang tidak disengaja (Tendai \& Crispen, 2009). Apabila suatu perusahaan mengelola in-store display dengan kreatif, seseorang yang datang di toko tersebut akan tertarik untuk melakukan pembelian (Jaya \& Suparna, 2018)

Dunia bisnis terus berkembang hingga saat ini, seperti halnya dengan Rena factory outlet. Rena factory outlet merupakan sebuah toko yang terletak di Tuban, Jawa Timur. Awalnya, Rena factory outlet hanya menjual produk pakaian wanita dan anak-anak saja. Namun, seiring berkembangnya teknologi informasi, Rena factory outlet berusaha untuk memenuhi kebutuhan dari setiap konsumennya. Kebutuhan wanita yang tiada habisnya membuat Rena factory outlet merasa tertarik untuk menyediakan kebutuhan skincare. Tempat khusus produk skincare diberi nama Rena beauty store. Rena beauty store menyediakan berbagai macam produk skincare pria dan wanita. Rena beauty store dipilih menjadi objek penelitian karena Rena beauty store merupakan toko yang menyediakan kebutuhan skincare yang sedang viral. Skincare viral yang dimaksud pada penelitian ini yaitu berbagai macam produk skincare yang banyak di-review oleh banyak pengguna social media seperti Tiktok, dan produk-produk tersebut dapat didapatkan di Rena beauty store Tuban, Jawa Timur (Rena, 2018) .

Social media marketing memiliki pengaruh yang signifikan pada niat beli konsumen (Balakrishnan et al., 2014). Kemudian, hasil penelitian tersebut berbeda dengan penelitian dari Sun \& Wang, (2020) yang mengatakan social media marketing tidak memiliki pengaruh yang signifikan terhadap niat beli konsumen. E-WOM memiliki pengaruh signifikan terhadap niat beli konsumen (Balakrishnan et al., 2014) namun hasil penelitian dari Torlak et al. (2014) mengatakan bahwa $e$-WOM tidak berpengaruh secara signifikan pada niat beli konsumen. Kemudian hasil penelitian dari Lange et al. (2016) menyatakan bahwa in-store display berpengaruh signifikan pada niat beli konsumen, namun penelitian tersebut berbeda hasil dengan penelitian Orth et al. (2016) yang menyatakan bahwa in-store display tidak memiliki pengaruh yang signifikan pada niat beli.

Tujuan penelitian ini yaitu menguji dan menganalisis pengaruh social media marketing, e-WOM, dan in-store display terhadap niat beli produk skincare.

\section{KAJIAN PUSTAKA DAN PENGEMBANGAN HIPOTESIS}

\section{Social Media Marketing}

Social media marketing merupakan strategi yang dilakukan oleh pebisnis untuk memasarkan suatu barang atau jasa melalui situs web atau media sosial dengan cara memanfaatkan komunitas yang memiliki masa yang banyak di social media (Weinberg, 2009). Social media marketing merupakan strategi mengenalkan sebuah produk ke masyarakat luas melalui situs online (As'ad, Abu-Rumman, \& Alhadid, 2014). Indikator yang digunakan untuk mengukur variabel social media marketing pada penelitian ini adalah online communities, interaction, sharing of content, accessibility, dan credibility (As'ad et al., 2014).

\section{Electronic Word of Mouth (e-WOM)}

Electronic word of mouth (e-WOM) diartikan sebagai kalimat baik atau buruk dari calon konsumen atau konsumen lama pada suatu barang atau perusahaan yang disediakan untuk masyarakat luas dan instansi dengan bantuan internet (Hennig-Thurau et al., 2004). E-WOM memiliki pengaruh yang signifikan terhadap niat beli terlepas dari jenis komunitas virtualnya (Balakrishnan et al., 2014). Indikator yang digunakan untuk mengukur variabel $e$-WOM pada penelitian ini yaitu intensity, valance of opinion, dan content (Goyette, Ricard, Bergeron, \& Marticotte, 2010). 


\section{In-store Display}

In-store display digambarkan sebagai tampilan sebuah toko yang dibuat semenarik mungkin untuk mencuri perhatian konsumen dengan tujuan menumbuhkan keinginan untuk membeli melalui daya tarik penglihatan langsung (direct visual appeal). In-store display merupakan sebuah media yang semakin banyak digunakan oleh para pebisnis untuk meningkatkan pengalaman berbelanja (Ortinau, Babin, \& Chebat, 2013). Desain visual dapat disesuaikan sesuai selera untuk menghasilkan respon yang diinginkan, seperti menimbulkan keinginan dan kesenangan (Rompay et al., 2012). Indikator yang digunakan untuk mengukur variabel in-store display dalam penelitian ini yaitu background music, store display, dan shop congestion (Tendai \& Crispen, 2009)

\section{Hubungan antar Variabel}

Social media marketing memiliki pengaruh yang signifikan pada niat beli konsumen (Balakrishnan et al., 2014). Social media marketing memiliki pengaruh signifikan pada niat beli konsumen (Novila Mileva, 2018), yang didukung juga oleh penelitian Abzari et al. (2014) bahwa social media marketing memiliki pengaruh yang signifikan pada niat beli konsumen. Penelitian tersebut berbeda hasil dengan penelitian Sun \& Wang (2020) yang menyatakan social media marketing tidak berpengaruh secara signifikan pada niat beli konsumen. Pemasaran digital dapat berdampak negatif jika dilakukan oleh penyedia layanan yang tidak terampil, yang artinya jika social media marketing tidak dikembangkan dan dikelola dengan baik dapat menyebabkan kegagalan dalam melakukan promosi, merusak nilai, meningkatkan biaya transaksi, biaya koordinasi, hilangnya nilai dan dampak negatif tentang manfaat jangka panjang (Aswani, Kar, Ilavarasan, \& Dwivedi, 2018).

H1: Ada pengaruh yang signifikan antara social media marketing terhadap niat beli.

E-WOM berpengaruh positif pada niat beli konsumen (Balakrishnan et al., 2014), kemudian hasil penelitian dari Wang et al. (2018a) juga menyatakan bahwa $e$-WOM berpengaruh positif terhadap niat beli konsumen. Hasil penelitian tersebut berbanding terbalik dengan penelitian Torlak et al. (2014) menyatakan bahwa $e$-WOM berpengaruh negatif pada niat beli, hal ini terjadi karena populasi dari penelitian.

$\mathrm{H} 2$ : Ada pengaruh yang signifikan antara $e$-WOM terhadap niat beli.

In-store display berpengaruh positif terhadap niat beli (Lange et al., 2016), selanjutnya penelitian Melina \& Kadafi (2017) juga menyatakan bahwa in-store display memiliki pengaruh yang positif dan signifikan, kemudian hasil penelitian dari Sugiarto \& Subagio (2014) juga menyatakan bahwa store atmosphere berpengaruh signifikan pada niat beli konsumen, begitu pula dengan hasil penelitian dari Orth et al. (2016) yang menyatakan bahwa in-store display berpengaruh negatif terhadap niat beli konsumen. Penelitian tersebut berbeda hasil dengan penelitian Gabrielli \& Cavazza (2014) yang mengatakan bahwa in-store display tidak memiliki pengaruh secara langsung pada niat beli.

H3: Ada pengaruh yang signifikan antara in-store display terhadap niat beli.

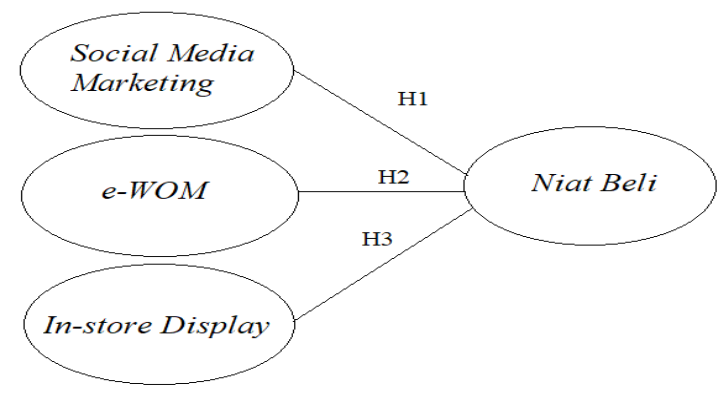

Gambar 1. KERANGKA KONSEPTUAL 
Heristya Putri. Sebuah Studi Niat Beli Skincare: Pengaruh Social media Marketing, E-WOM, dan Instore Display

\section{METODE PENELITIAN}

Penelitian ini menggunakan metode penelitian kuantitatif. Karakteristik responden pada penelitian ini yakni seorang laki-laki atau perempuan yang telah melihat Tiktok dari Rena beauty store dan belum pernah melakukan pembelian produk skincare di Rena beauty store, rentang usia dari responden yaitu 17-35 tahun. Sampel yang digunakan dalam penelitian ini adalah non-probability sampling dengan Teknik pengambilan sampel judgmental sampling. Jumlah sampel dalam penelitian ini adalah 100 orang. Dalam penelitian ini menggunakan metode pengumpulan data dengan angket yang disebarkan secara online (melalui social media seperti Whatsapp dan Instagram story) menggunakan Google form kepada responden. Teknik analisis data dalam penelitian ini yaitu regresi linier berganda dengan menggunakan SPSS versi 26.

\section{HASIL DAN PEMBAHASAN}

\section{Karakteristik Responden}

Tabel 1.

KARAKTERISTIK RESPONDEN

\begin{tabular}{llrr}
\hline \multicolumn{2}{c}{ Karakteristik } & Jumlah & Persentase \\
\hline Jenis Kelamin & Perempuan & 81 & $81 \%$ \\
& Laki-laki & 19 & $19 \%$ \\
\multirow{3}{*}{ Usia } & $17-20$ & 14 & $14 \%$ \\
& $21-24$ & 81 & $81 \%$ \\
Pekerjaan & $25-28$ & 5 & $5 \%$ \\
& $29-32$ & - & - \\
& $33-35$ & - & - \\
& Pelajar/Mahasiswa & 76 & $76 \%$ \\
& Guru/Dosen & - & - \\
Kocial media yang & Karyawan & 18 & $18 \%$ \\
& Wiraswasta & - & - \\
& Lainnya & 6 & $6 \%$ \\
& TikTok & 59 & $27,69 \%$ \\
& Instagram & 87 & $40,84 \%$ \\
& Facebook & 33 & $15,49 \%$ \\
& Twitter & 22 & $10,32 \%$ \\
& Lainnya & 12 & 5,63 \\
\hline Sumber: Output SPSS versi 26 (2021, data diolah) & &
\end{tabular}

Tabel 1 menunjukkan bahwa responden dari penelitian ini adalah responden perempuan dengan jumlah 81 responden atau sebesar $81 \%$, dan sisanya adalah responden laki-laki dengan total 19 responden atau sebesar 19\%. Responden yang mengisi penelitian ini memiliki rentang usia yang berbeda-beda, responden dengan usia 17-20 tahun sebesar14\%, responden dengan rentang usia 21-24 sebesar $81 \%$, dan sisanya adalah responden dengan rentang usia 25-28 tahun sebesar 5\%. Responden yang mendominasi pada penelitian ini yaitu seorang responden dengan pekerjaan sebagai pelajar atau mahasiswa dengan total $76 \%$, selanjutnya responden yang bekerja sebagai karyawan dengan total $18 \%$, dan sisanya sebanyak $6 \%$ bekerja yang lainnya. Responden yang menggunakan social media Tiktok yaitu sebanyak $59(27,69 \%$, ) kemudian responden yang menggunakan social media Instagram mendominasi pada penelitian ini yaitu sebanyak 87 (40,84\%), selanjutnya responden yang menggunakan social media facebook sebanyak $33(15,49 \%)$, lalu responden yang menggunakan social media Twitter sebanyak $22(10,32 \%)$, dan sisanya menjawab menggunakan lainnya sebanyak $12(5,63 \%)$. 


\section{Uji Validitas dan Reliabilitas}

\section{HASIL UJI VALIDITAS DAN RELIABILITAS}

\begin{tabular}{|c|c|c|}
\hline Variabel dan Pernyataan & Cronbach's Alpha & r-hitung \\
\hline Social media marketing (X1) & 0,854 & \\
\hline $\begin{array}{l}\text { Social media dari Rena beauty store selalu membagikan } \\
\text { informasi tentang produk skincare. }\end{array}$ & & 0,742 \\
\hline $\begin{array}{l}\text { Saya selalu mencari tahu tentang perkembangan produk } \\
\text { skincare melalui social media dari Rena beauty store. }\end{array}$ & & 0,626 \\
\hline $\begin{array}{l}\text { Saya selalu mendapatkan informasi baru mengenai produk } \\
\text { skincare dari social media milik Rena beauty store. }\end{array}$ & & 0,752 \\
\hline $\begin{array}{l}\text { Saya merasa bahwa social media milik Rena beauty store } \\
\text { lebih up to date daripada yang lainnya. }\end{array}$ & & 0,689 \\
\hline $\begin{array}{l}\text { Saya dapat menerima informasi mengenai produk skincare } \\
\text { dari social media milik Rena beauty store dengan mudah. }\end{array}$ & & 0,797 \\
\hline$e-W O M(\mathrm{X} 2)$ & 0,848 & \\
\hline $\begin{array}{l}\text { Saya sering berkonsultasi pada forum Rena beauty store } \\
\text { untuk menentukan produk yang akan saya beli. }\end{array}$ & & 0,571 \\
\hline $\begin{array}{l}\text { Saya sering mengumpulkan informasi tentang review } \\
\text { produk dari konsumen Rena beauty store secara online } \\
\text { sebelum melakukan pembelian. }\end{array}$ & & 0,707 \\
\hline $\begin{array}{l}\text { Saya merasa percaya diri untuk membeli sebuah produk } \\
\text { setelah membaca review produk dari Rena beauty store. }\end{array}$ & & 0,757 \\
\hline $\begin{array}{l}\text { Kolom komentar pada content milik Rena beauty store } \\
\text { selalu menjelaskan manfaat atas sebuah produk. }\end{array}$ & & 0,757 \\
\hline In-store display (X3) & 0,885 & \\
\hline $\begin{array}{l}\text { Musik latar menambah kenyamanan saya saat berada di } \\
\text { Rena beauty store. }\end{array}$ & & 0,536 \\
\hline Layout di Rena beauty store sangat menarik. & & 0,474 \\
\hline $\begin{array}{l}\text { Tulisan yang terdapat di Rena beauty store memudahkan } \\
\text { saya untuk menemukan produk yang saya cari. }\end{array}$ & & 0,656 \\
\hline Penarangan di Rena beauty store sangat baik. & & 0,648 \\
\hline Rena beauty store selalu ramai oleh pengunjung & & 0,589 \\
\hline Niat Beli (Y) & 0,835 & \\
\hline Saya tertarik untuk membeli produk skincare. & & 0,681 \\
\hline Saya akan membeli produk skincare. & & 0,634 \\
\hline $\begin{array}{l}\text { Saya akan rutin untuk membeli produk skincare sebagai } \\
\text { perawatan wajah saya. }\end{array}$ & & 0,570 \\
\hline $\begin{array}{l}\text { Saya tidak pernah merasa ragu apabila saya akan membeli } \\
\text { produk skincare. }\end{array}$ & & 0,513 \\
\hline $\begin{array}{l}\text { Produk skincare merupakan kebutuhan yang sangat } \\
\text { penting bagi saya }\end{array}$ & & 0,669 \\
\hline
\end{tabular}

Sumber: Output SPSS versi 26 (2021)

Uji validitas bertujuan untuk mengukur pernyataan angket dapat mempresentasikan apa yang diukur oleh kuesioner dalam penelitian tersebut maka dianggap valid. Angket disebarkan kepada 30 responden yang bukan termasuk 100 responden. Uji validitas dikatakan valid apabila r-hitung lebih besar dari r-tabel dan bernilai positif. Pernyataan yang memiliki nilai r-hitung $(<0,361)$ dikatakan tidak valid (Ghozali, 2016). Berdasarkan tabel 2 hasil uji validitas, semua item pertanyaan pada instrumen penelitian dinyatakan valid, karena r-hitung lebih $>$ dari r-tabel $(0,361)$. Sehingga, pernyataan dapat dipakai sebagai alat ukur pengaruh social media marketing, e-WOM, dan in-store display terhadap niat beli. 
Heristya Putri. Sebuah Studi Niat Beli Skincare: Pengaruh Social media Marketing, E-WOM, dan Instore Display

Uji reliabilitas bertujuan untuk mengetahui instrumen pernyataan dalam memberikan gambaran seberapa jauh hasil pengukuran dengan alat tersebut dapat dipercaya sebagai indikator. Untuk menguji reliabilitas, penyebaran angket dilakukan kepada 30 responden yang bukan merupakan sampel dan dilakukan uji dengan menggunakan SPSS yang dapat dilihat dari uji statistik Cronbach alpha. Hasil dari perhitungan setiap variabel dikatakan reliabel jika nilai Cronbach alpha $>70$. Berdasarkan tabel 2, nilai Cronbach alpha untuk variabel social media marketing 0,854>0,70;e-WOM 0,848>0,70; in-store display 0,885 > 0,70; niat beli 0,835 > 0,70. Sehingga, pernyataan-pernyataan pada instrumen penelitian dikatakan reliabel dan dapat digunakan.

\section{Uji Asumsi Klasik}

Uji asumsi klasik dalam penelitian ini terdiri dari uji normalitas, uji multikolinieritas, uji heteroskedastisitas serta uji kelayakan model. Pada uji normalitas, model memenuhi asumsi normalitas karena Kolmogorov-Smirnov lebih besar dari 0,05 yakni sebesar 0,064. Uji multikolinieritas pada penelitian ini dinyatakan tidak terjadi multikolinieritas, dibuktikan dengan hasil uji multikolinieritas untuk masing-masing variabel, yakni social media marketing memiliki nilai tolerance $0,454 \geq 0,1, e$-WOM memiliki nilai tolerance $0,486 \geq 0,1$, in-store display memiliki nilai tolerance $0,906 \geq 0,1$. Uji Heteroskedastisitas pada penelitian ini menggunakan scatterplots. Hasil gambar pada scatterplots yakni, titik-titik menyebar di atas dan di bawah angka 0 pada sumbu Y. Hal ini mengartikan tidak terdapat gejala heteroskedatisitas. Sehingga penelitian ini mempunyai persamaan variance residual dalam suatu periode pengamatan dengan periode pengamatan yang lain.

Dalam uji kelayakan model menghasilkan kontribusi variabel independen, social media marketing (X1), e-WOM (X2), dan in-store display (X3) terhadap variabel dependen niat beli (Y) sebesar 0,245 $=24,5 \%$ yang berarti social media marketing, e-WOM, dan in-store display berpengaruh pada Niat beli sebesar $24,5 \%$ dan $75,5 \%$ dipengaruhi oleh variabel lain di luar variabel pada penelitian ini.

\section{Uji Hipotesis}

Tabel 3.

HASIL UJI T

\begin{tabular}{lcl}
\hline \multicolumn{1}{c}{ Variabel } & t & Sig. \\
\hline (Constant) & 2.783 & .006 \\
Social media marketing & 2.263 & .026 \\
e-WOM & 1.904 & .060 \\
In-store display & -.246 & .806 \\
\hline
\end{tabular}

Sumber: Output SPSS versi 26 (2021)

Hasil uji t pada tabel 3, social media marketing (X1) memiliki nilai 0,026 $<0,050$, angka tersebut mengindikasikan bahwa variabel social media marketing (X1) berpengaruh signifikan terhadap niat beli (Y). Variabel $e-W O M(\mathrm{X} 2)$ memiliki nilai $0,060>0,050$, angka tersebut mengindikasikan bahwa variabel $e-W O M(\mathrm{X} 2)$ tidak memiliki pengaruh signifikan terhadap niat beli (Y). Variabel in-store display (X3) memiliki nilai 0,806 >0,050, angka tersebut mengindikasikan bahwa variabel in-store display (X3) tidak memiliki pengaruh signifikan terhadap niat beli (Y).

\section{Pengaruh Social Media Marketing terhadap Niat Beli}

Penelitian ini menghasilkan pengaruh social media marketing terhadap niat beli secara signifikan. Hal ini mengartikan jika social media marketing ditingkatkan maka akan meningkatkan niat beli konsumen, karena salah satu faktor yang memengaruhi niat beli adalah social media marketing. Social media marketing yang dilakukan oleh Rena beauty store yaitu dengan cara membuat akun Tiktok, Instagram, dan Facebook, seperti yang kita tahu bahwa social media saat ini juga digunakan oleh banyak orang untuk berjualan secara online. Rena beauty store membuat content menarik di Tiktok seperti challenge membeli produk skincare dengan budget Rp20.000 tetapi sudah bisa mendapat beberapa produk dari Rena beauty store. Hal ini dikarenakan Rena beauty store menjual bermacammacam produk mulai dari harga yang murah hingga mahal. Social media marketing lainnya yang dilakukan oleh Rena beauty store yaitu dengan cara me-review produk skincare viral yang telah dijual 
di Rena beauty store, hal ini dapat menginformasikan para followers Rena beauty store di social media bahwa beberapa produk viral telah dijual di Rena beauty store. Rena beauty store juga menginformasikan pada followers nya apabila ada promo atau potongan harga dari produk skincare yang dijual. Sehingga hal ini membuktikan penelitian Balakrishnan et al. (2014) social media marketing memiliki pengaruh yang signifikan terhadap niat beli konsumen. Hasil penelitian ini juga mendukung penelitian As'ad et al. (2014) bahwa social media marketing berpengaruh signifikan. Penelitian Abzari et al. (2014) menyatakan bahwa social media berpengaruh signifikan terhadap niat beli. Penelitian Azaria (2014) juga menunjukkan internet marketing berpengaruh signifikan. Sugianto (2016) menyatakan bahwa social media berpengaruh signifikan terhadap niat beli konsumen, penelitian Ekasari (2014) social media berdampak positif dan signifikan, hal ini juga juga mendukung fenomena yang ada, di mana social media marketing yang dimiliki oleh Rena beauty store selalu membuat content yang menarik dan menghibur dengan tujuan untuk menarik perhatian konsumen lama dan konsumen baru.

Berdasarkan dengan hasil dari karakteristik responden, mayoritas responden yaitu responden perempuan memiliki usia 21-24 tahun dan pernah melihat content TikTok dari Rena beauty store. Responden dengan karakteristik demikian sangat aktif di social media dan sering kali menggunakan social media untuk melihat review produk skincare, sehingga dapat memunculkan niat mereka untuk membeli produk skincare di Rena beauty store.

\section{Pengaruh E-WOM terhadap Niat Beli}

Hasil penelitian menunjukkan bahwa $e$-WOM tidak berpengaruh secara signifikan terhadap niat beli. Hal ini membuktikan penelitian yang dikemukakan oleh penelitian Torlak et al. (2014) menyatakan bahwa $e$-WOM tidak berpengaruh secara signifikan pada niat beli. Hasil ini tidak sama dengan penelitian yang dilakukan oleh Balakrishnan et al. (2014) yang menyatakan bahwa e-WOM berpengaruh positif pada niat beli konsumen, begitu pula dengan penelitian Wang et al. (2018b) yang mengatakan bahwa $e$-WOM berpengaruh positif terhadap niat beli konsumen.

Responden perempuan maupun laki-laki tidak terlalu menggunakan fitur kolom komentar pada content milik Rena beauty store. Hal ini bisa saja dikarenakan followers Rena beauty store telah mengetahui manfaat suatu produk melalui sumber lainnya seperti influencer, beauty blogger, dan content lain, sehingga sudah memiliki bekal pengetahuan dari sumber lainnya. Hal ini menyebabkan $e$-WOM tidak berpengaruh signifikan terhadap niat beli produk skincare di Rena beauty store.

\section{Pengaruh In-store Display terhadap Niat Beli}

Hasil penelitian menunjukkan bahwa in-store display tidak memiliki pengaruh secara signifikan terhadap niat beli konsumen. Sehingga membuktikan penelitian Gabrielli \& Cavazza (2014) yang mengatakan bahwa in-store display tidak berpengaruh secara langsung terhadap niat beli konsumen. Bertentangan dengan penelitian Lange et al. (2016) yang menyatakan bahwa in-store display berpengaruh secara signifikan terhadap niat beli, begitu pula dengan penelitian Melina \& Kadafi (2017) dan Ortinau et al. (2013) yang juga menyatakan bahwa in-store display berpengaruh secara signifikan terhadap niat beli konsumen.

Berdasarkan hasil karakteristik responden, baik perempuan maupun laki-kali di mana saja berada dapat mengisi kuesioner ini secara online melalui google form, dan beberapa di antaranya belum pernah mengunjungi Rena beauty store di Tuban-Jawa timur secara langsung. Dengan kata lain responden hanya melihat display dari Rena beauty store secara virtual melalui social media, sehingga mereka tidak dapat merasakan suasana toko secara langsung, dan hal inilah yang menyebabkan instore display tidak berpengaruh signfikan pada niat beli produk skincare di Rena beauty store.

\section{KESIMPULAN}

Penelitian ini menunjukkan adanya pengaruh secara signifikan antara social media marketing pada niat beli (Studi pada konsumen Rena beauty store-Tuban), e-WOM tidak memiliki pengaruh secara 
Heristya Putri. Sebuah Studi Niat Beli Skincare: Pengaruh Social media Marketing, E-WOM, dan Instore Display

signifikan pada niat beli (Studi pada konsumen Rena beauty store-Tuban), kemudian In-store display tidak memiliki pengaruh secara signifikan pada niat beli (Studi pada konsumen Rena beauty storeTuban).

Penelitian selanjutnya dapat melibatkan variabel kemudahan, promosi, atau kualitas layanan. Untuk mendapatkan hasil yang berbeda, penelitian selanjutnya dapat menggunakan objek lainnya, misalnya menggunakan objek pada perusahaan jasa seperti klinik kecantikan yang saat ini juga sangat digemari oleh masyarakat khusunya remaja, di mana di usia remaja seseorang akan mementingkan penampilan mereka. Untuk lebih memperkuat hasil penelitian selanjutnya, hal yang dapat dilakukan adalah melakukan penelitian secara offline. Kelemahan pada penelitian ini terletak pada penyebaran angket yang dilakukan secara online, mengingat pada penelitian ini terdapat variabel in-store display yang seharusnya penelitian ini dilakukan secara offline dengan tujuan untuk mendapatkan hasil yang lebih maksimal.

\section{DAFTAR PUSTAKA}

Abzari, M., Ghassemi, R. A., \& Vosta, L. N. (2014). Analysing the Effect of Social Media on Brand Attitude and Purchase Intention: The Case of Iran Khodro Company. Procedia - Social and Behavioral Sciences, 143, 822-826. https://doi.org/10.1016/j.sbspro.2014.07.483

As'ad, Abu-Rumman, H., \& Alhadid, A. Y. (2014). The Impact of Social Media Marketing on Brand Equity: an Empirical Study on Mobile Service Providers in Jordan. Rev. Integr. Bus. Econ. Res, 3(1), 315-326. Retrieved from https://docplayer.net/2113209-The-impact-of-social-mediamarketing-on-brand-equity-an-empirical-study-on-mobile-service-providers-in-jordan.html

Aswani, R., Kar, A. K., Ilavarasan, P. V., \& Dwivedi, Y. K. (2018). Search Engine Marketing is Not All Gold: Insights from Twitter and SEOClerks. International Journal of Information Management, 38(1), 107-116. https://doi.org/10.1016/j.ijinfomgt.2017.07.005

Azaria, P. (2014). Pengaruh Internet Marketing terhadap Pembentukkan Word of Mouth dan Efektivitas Iklan dalam Meningkatkan Brand Awareness (studi pada follower akun twitter pocari sweat di jejaring sosial twitter). Jurnal Administrasi Bisnis S1 Universitas Brawijaya, 13(1), $83875 . \quad$ Retrieved from http://administrasibisnis.studentjournal.ub.ac.id/index.php/jab/article/view/538

Balakrishnan, B. K. P. D., Dahnil, M. I., \& Yi, W. J. (2014). The Impact of Social Media Marketing Medium toward Purchase Intention and Brand Loyalty among Generation Y. Procedia - Social and Behavioral Sciences, 148, 177-185. https://doi.org/10.1016/j.sbspro.2014.07.032

Cakra, S. (2020). Dampak Tik-Tok pada Generasi Sosial Millenial. Retrieved November 17, 2020, from Kumparan website: https://kumparan.com/satria-cakra/dampak-tik-tok-pada-generasisosial-millenial-1v1sLqjPUCP/full

Dewi, P. L. (2020). Pentingnya Penggunaan Tiktok Hashtag dan Tips Penggunaannya. Retrieved November 17, 2020, from Kompasiana website: https://www.kompasiana.com/lynna123/5ec3909ed541df214c3b7f53/pentingnya-tiktokhashtag-dan-tips-penggunaannya?page=all

Ekasari, N. (2014). Pengaruh Promosi Berbasis Sosial Media terhadap Keputusan Pembelian Produk Jasa Pembiayaan Kendaraan pada PT. BFI Finance Jambi. Journal of Chemical Information and Modeling, 16, 81-102. Retrieved from https://www.neliti.com/publications/43450/pengaruh-promosi-berbasis-sosial-media-terhadapkeputusan-pembelian-produk-jasa

Franedya, R. (2020). Berapa Pengguna Aktif TikTok di Dunia? Jangan Kaget Yah! Retrieved 
November 17, 2020, from CNBC website: https://www.cnbcindonesia.com/tech/20200825104121-37-181742/berapa-pengguna-aktiftiktok-di-dunia-jangan-kaget-yah

Gabrielli, V., \& Cavazza, N. (2014). The Influence of In-Store Product Holders on Orientation towards the Product And On Purchase Intention. International Review of Retail, Distribution and Consumer Research, 24(3), 311-327. https://doi.org/10.1080/09593969.2013.862507

Ghozali, I. (2016). Aplikasi Analisis Multivariete. Semarang: Badan Penerbit Universitas Diponegoro.

Goyette, I., Ricard, L., Bergeron, J., \& Marticotte, F. (2010). E-WOM Scale: Word-of-Mouth Measurement Scale for E-services Context. Canadian Journal of Administrative Sciences / Revue Canadienne Des Sciences de l'Administration, 27(1), 5-23. https://doi.org/10.1002/cjas.129

Hennig-Thurau, T., Gwinner, K. P., Walsh, G., \& Gremler, D. D. (2004). Electronic Word-of-Mouth via Consumer-Opinion Platforms: What Motivates Consumers to Articulate Themselves on the Internet? Journal of Interactive Marketing, 18(1), 38-52. https://doi.org/10.1002/dir.10073

Jaya, H. S., \& Suparna, G. (2018). Pengaruh Atmosfer Toko dan Kesesuaian Harga terhadap Keputusan Pembelian Konsumen pada Temday Store Denpasar. E-Jurnal Manajemen Universitas Udayana, 7(6), 2887. https://doi.org/10.24843/ejmunud.2018.v07.i06.p02

Kotler, P., \& Keller, K. L. (2016). Marketing Management 15th Edition (15th ed.). Harlow: Pearson.

Lange, F., Rosengren, S., \& Blom, A. (2016). Store-window Creativity's Impact on Shopper Behavior. Journal of Business Research, 69(3), 1014-1021. https://doi.org/10.1016/j.jbusres.2015.08.013

Melina, \& Kadafi, M. A. (2017). Pengaruh Price Discount dan In-store display terhadap Impulse Buying. Forum Ekonomi, Vol.19(No.2), 201-209. Retrieved from http://journal.feb.unmul.ac.id/index.php/FORUMEKONOMI

Novila Mileva, D. (2018). Pengaruh Social Media Marketing dan Persepsi Kualitas terhadap Niat Beli Surabaya Snowcake (Studi pada Masyarakat Surabaya timur). Jurnal Ilmu Manajemen (JIM), 7(2), 446-452. Retrieved from https://jurnalmahasiswa.unesa.ac.id/index.php/jim/article/view/26413/24188

Orth, U. R., Wirtz, J., \& McKinney, A. (2016). Shopping Experiences in Visually Complex Environments: A self-regulation account. Journal of Service Management, 27(2), 194-217. https://doi.org/10.1108/JOSM-10-2014-0268

Ortinau, D. J., Babin, B. J., \& Chebat, J. C. (2013). Development of New Empirical Insights in Consumer-retailer Relationships within Online and Offline Retail Environments: Introduction to the special issue. Journal of Business Research, 66(7), 795-800. https://doi.org/10.1016/j.jbusres.2011.06.003

Ramadhani, N. (2020). Ini Dampak Perkembangan Teknologi yang Dapat Dirasakan. Retrieved November 17, 2020, from Akselaran website: https://www.akseleran.co.id/blog/perkembanganteknologi/

Rena. (2018). Tentang Rena Beauty Store. Retrieved November 17, 2020, from Shopee website: https://shopee.co.id/renabeautystore

Sari, L. (2020). TikTok Paling Banyak Diunduh Pengguna di Indonesia. Retrieved November 17, 
Heristya Putri. Sebuah Studi Niat Beli Skincare: Pengaruh Social media Marketing, E-WOM, dan Instore Display

2020, from jpnn website: https://www.jpnn.com/news/tiktok-paling-banyak-diunduh-penggunadi-indonesia

Sugianto Putri, C. (2016). Pengaruh Media Sosial terhadap Keputusan Pembelian Konsumen Cherie melalui Minat Beli. PERFORMA: Jurnal Manajemen Dan Start-Up Bisnis, 1(5), 594. Retrieved from https://journal.uc.ac.id/index.php/performa/article/view/348

Sugiarto, B. U., \& Subagio, H. (2014). Analisa Pengaruh Produk, Kualitas Pelayanan, Harga, dan Store Atmosphere terhadap Minat Beli di Dream of Khayangan Art Resto Surabaya. Jurnal Manajemen Pemasaran Petra, 2(1), 1-14. Retrieved from https://www.neliti.com/publications/140482/

Sun, Y., \& Wang, S. (2020). Understanding Consumers' Intentions to Purchase Green Products in the Social Media Marketing Context. Asia Pacific Journal of Marketing and Logistics, 32(4), 860878. https://doi.org/10.1108/APJML-03-2019-0178

Tendai, M., \& Crispen, C. (2009). In-Store Shopping Environment and Impulsive Buying. African Journal of Marketing Management, 1(4), 102-108. Retrieved from https://academicjournals.org/journal/AJMM/article-full-text-pdf/26228BD1944

Torlak, O., Ozkara, B., Tiltay, M., Cengiz, H., \& Dulger, M. (2014). The Effect of Electronic Word of Mouth on Brand Image and Purchase Intention: an Application Concerning Cell Phone Brands for Youth Consumers in Turkey. Journal of Marketing Development and Competitiveness, 8(2), 61. Retrieved from https://www.researchgate.net/publication/283723484_The_Effect_of_Electronic_Word_of_Mo uth_on_Brand_Image_and_Purchase_Intention_An_Application_Concerning_Cell_Phone_Bra nds_for_Youth_Consumers_in_Turkey

Van Rompay, T. J. L., Tanja-Dijkstra, K., Verhoeven, J. W. M., \& van Es, A. F. (2012). On store Design and Consumer Motivation: Spatial Control and Arousal in the Retail Context. Environment and Behavior, 44(6), 800-820. https://doi.org/10.1177/0013916511407309

Wang, J. J., Wang, L. Y., \& Wang, M. M. (2018a). Understanding the Effects of eWOM Social Ties on Purchase Intentions: a Moderated Mediation Investigation. Electronic Commerce Research and Applications, 28, 54-62. https://doi.org/10.1016/j.elerap.2018.01.011

Wang, J. J., Wang, L. Y., \& Wang, M. M. (2018b). Understanding the Effects of eWOM Social Ties on Purchase Intentions: a Moderated Mediation Investigation. Electronic Commerce Research and Applications, 28, 54-62. https://doi.org/10.1016/j.elerap.2018.01.011

Weinberg, T. (2009). The New Community Rules: Marketing on the Social Web. Sebastopol, CA: O'Reilly Media, Inc. 